\title{
Didactic Approaches to the Application of Cross-Curricular Topics in Secondary Vocational Education
}

\author{
DKarel Nemejc ${ }^{1}$ Ing., Ph.D.; Radmila Dytrtova ${ }^{2}$ PhDr., CSc. \\ (D) Katerina Tomsikova ${ }^{3}$ Ing.; Jiri Sedivy ${ }^{4}$ Mgr.
}

Czech University of Life Sciences Prague, Institute of Education and Communication, Czech Republic nemejc@ivp.czu.cz'; dytrtovar@ivp.czu.cz²; tomsikova@ivp.czu.cz ${ }^{3}$; sedivyj@ivp.czu.cz ${ }^{4}$

\begin{abstract}
Modern society is often referred to as a society of knowledge and information. In this context, activating methods are experiencing a renaissance. Such methods offer students the opportunity to progress to perceive more accurately and comprehensively, recognize and experience stimuli, develop their perception and thinking, effectively solve problems, communicate and act objectively and successfully. It can be an active teaching and learning that is the way that can contribute to such a goal in the era of systematic cognition and differentiation of information, raising living standards, changing lifestyles, and globalizing the world. The question is how to bridge this epoch in the sense of preparing students for their active roles as inhabitants of the planet, accepting a responsible way of life in line with sustainable development. It is especially important for environmental education to understand the context and learn interdisciplinary, comprehensively, to be able to distinguish values, to take interest in and get to know one's surroundings, to discover, to take the initiative and to be sensitive and receptive as well. Therefore, it is necessary to think about the didactic methods that teachers use in their lessons and focus on activating methods and forms of teaching, leading to the fulfilment of such sub-objectives. In this context, the aim of the paper is to introduce and analyse new activating didactic approaches to the implementation of the cross-curricular topic "Man and the environment" as designed by graduate students of the Institute of Education and Communication at the Czech University of Life Sciences Prague between the academic years 2019 and 2020. Didactic approaches (such as project-based learning, field learning with the support of worksheets, and the use of nature educational trails) applicable in practice were designed for selected localities, focusing on increasing the interest and awareness of secondary and secondary vocational school students about their surrounding natural environment.
\end{abstract}

Keywords: environmental education, secondary vocational education, cross-curricular topics, didactic approaches, awareness.

\section{Introduction}

Active teaching and learning are based on learning, discovery, critical thinking, mutual cooperation and application of what has been learned. We live in a time that has spanned the era of systematic cognition and differentiation of a wealth of information from many disciplines, which has contributed to raising living standards, changing lifestyles and production patterns, but also to globalizing the world and related environmental and social issues. The decision needed is how to bridge this epoch, how to prepare students for their active roles as inhabitants of the planet (Nováková, Němejc, Dytrtová, 2018). It can be active teaching and learning that is the way that can contribute to such a goal. It is especially important for environmental education to understand the context and learn interdisciplinary, comprehensively, to be able to distinguish values, to take interest in and get to know one's surroundings, to discover, to take the initiative and to be sensitive and receptive as well. Therefore, it is necessary to think about the didactic methods that teachers use in their lessons and focus on activating methods and forms of teaching, leading to the fulfilment of such sub-objectives (Ehrlich, 2011). As a result of innovative processes taking place in modern society is developing a new system of educational values. New paradigms resulted in a review of approaches to the development of vocational education strategies, focusing on personal approaches to teaching and education (Zhanguzhinova, Magauova, Nauryzbaeva, 2016). The assigned topic of graduate thesis: "On the way to school" for students of the study programme of vocational education, implemented by the Institute of Education and Communication at the Czech University of Life Sciences Prague was an incentive to find new activating didactic approaches for future teachers, as they need to be constantly found and innovated, as confirmed, for example, by P. Sjoblom and L.A. Wolff (2017), M. Cyrankowska, J. Kostecka, A. Mazur-Paczka (2019), and D. Vasilevska and A. Geske (2020). 
The demand for active teaching as one of the ways to bridge the crisis of a "static" learning culture is not new, as was stated, for example, at the UNESCO meeting in 1997 (Scoullos, 1998). Many universities that prepare teachers have been dealing with this issue for a long time. In the application of active teaching and learning to environmental education, the situation at schools and in the preparation of teachers in the Czech Republic was described and commented on in several of outputs published abroad over the past twenty years (Dytrtova, 2003; Dytrtova, 2005; Dytrtova, 2006; Dytrtova, 2007; Dytrtova, Nemejc, 2018). Methods and forms that support active learning include problem-based teaching, student projects, discussions, fieldwork, observation (especially phenological observations), educational trails, and student conferences.

An ethical attitude towards nature and the environment and critical thinking are a prerequisite for environmental awareness and active responsible behaviour. Most people have a need for contact with nature; this need is often associated with aesthetic experience or active activity in nature. Admiration for nature in adults and knowledge of nature and its products in children often means - what I know, I do not destroy. However, the relationship and behaviour of individuals to nature can be very different. In the field of environmental psychology and ecopsychology, some authors address the question whether or not a person sensitive and receptive to nature also protects it (Mackay, Schmitt, 2019) and tries to characterize the typology of man's relationship to nature. The presented characteristics take into account various attributes - e.g., the need for contact with nature, the degree of adaptation to change, the strength of an anthropocentric attitude to nature compared to the biocentric attitude - man is the master in nature and controls it (passive observer - active protector).

It is typical for these days that people's relationships and behaviour towards nature and the environment are contradictory - even those who love nature do not always behave responsibly towards it. Classification according to the typology of man's relationship to nature is therefore problematic and thus we will not follow it, nor due to their low effectiveness, we will use typologies by other authors already published.

Teacher is a bearer of eco-literacy and co-creates an attitude towards nature and the environment in their students. The basis of the appropriate attitude, relationship and behaviour is the perception of the environment, nature and cognition itself, getting acquainted with the environment "where I live, where I go to school". Based on this, an assessment of the quality of the environment is created, combined with critical thinking and action in favour of the sustainability of the appropriate level of quality of the environment and life in it. This is therefore our long-term goal - the goal of environmental education and the effort to prepare teachers to fulfil this goal. It is necessary to realize that this is only a part of the process, because the role of the student is the only an episode within his / her path of life, when values and environmental insights can change.

Regarding the above-mentioned, the aim of the article is to introduce and analyse new activating didactic approaches to the implementation of the cross-curricular topic "Man and the environment" as designed by graduate students of the Institute of Education and Communication at the Czech University of Life Sciences Prague between the academic years 2018-2019 and 2019-2020.

\section{Methodology}

The design of future teachers of vocational subjects for new approaches to the application of the crosscurricular topic "Man and the environment" is based on the topics of graduate thesis. In this respect, didactic approaches with the emphasis on the perception of surroundings and natural environment (natural and historical values, awareness increasing, natural monuments, trees, life near the river, bird nests, and many other specific areas) of students of secondary and secondary vocational schools have been found.

In other words, "On the Way to School: The Awareness of Students of Secondary Vocational Schools about their Surrounding Natural Environment" is a topic and at the same time a chance to get acquainted with the surroundings of the school, discover the unknown, critically judge, and actively participate. The authors of the graduate thesis made their proposals for didactic procedures and innovations based on their own ideas, experience and creativity. In this regard, the authors of the submitted graduate theses initially studied and analysed the literature dealing with the issue to extend their knowledge. On a practical level, they were acquainted in detail and assessed the surrounding natural environment of the selected localities. Didactic approaches with emphasis on their appropriate application in practice and the resulting desired 
impacts were presented. The above-mentioned was professionally led by the supervisors, who continuously discussed the solutions and didactic approaches with the authors, encouraged them and supervised the empirical process of elaboration of theses.

The graduate theses were written and defended by the authors in the academic years 2018-2019 and 2019-2020. Selected results of the four graduate theses are provided in the following chapter.

\section{Results and Discussion}

The chapter presents selected didactic approaches and their examples, as designed by students of teacher training programmes at the Institute of Education and Communication of the Czech University of Life Sciences Prague.

\section{The didactic approach by S. Svacek (2019): Project-based learning}

The didactic procedure designed by S. Svacek (2019) focuses on the application of the cross-curricular topic "Man and the environment" through project-based learning for students in the first to fourth years of secondary education. The author is aware of that environmental education provides information to the public, from the youngest to older generations. It helps to create a positive relationship with the surrounding natural environment. The intention of the author's didactic approach is the verification of students' attitudes and raising their awareness about their surrounding natural environment. Here, the activities are focused on a specific secondary school and its surroundings.

Such an approach was designed within a graduate thesis. The author focused in details on the analysis of the region near a selected secondary vocational school of the Czech Republic. The proposed activity should stimulate and increase the interest in the surrounding natural environment of the students during the processing of their project. Its use is possible both outside nearby the school and in group teaching and independent work of students at school. The advantage of such an approach is the possible application regardless of the specific secondary vocational school or region. As a part of the project, students, in groups, map the terrain in the given localities, take a photo documentation, discuss, focus mainly on evidence of environmental damage around their school (such as waste management, black dumps, noise sources, watercourse cleanliness, state of greenery, neglected areas...). Students then suggest ways to improve, use or remedy these localities based on their findings. The output of the project is a comprehensive material of localities and phenomena that need to be solved from the students' point of view.

Furthermore, another output of activities is a "student ecological audit" of the area of interest, where students rate areas such as, e.g., waste management, transport, energy, air pollution, water management, and others, and find suitable solutions and recommendations for the management of the town.

\section{The didactic approach by J. Hyklova (2019) and V. Sedivy (2020): Field learning with the support of worksheets}

Young people spend most of their time in the virtual world on the computer and do not know life and the world around them. The authors of this didactic approach assume that the right to a healthy environment is already enshrined in the Charter of Fundamental Rights and Freedoms. One of the ways to improve the current - not very positive state of the environment is, in addition to restrictions, environmental education and training. As a result, this didactic approach was designed with the aim to increase students' awareness of their surrounding natural environment on their everyday way to school. For these purposes, on the basis of theoretical background and legislation, activation means were designed to motivate students to increase their interest in their environment. In the first phase, preparation for field teaching and learning in the natural environment of a selected region of the Czech Republic was proposed for teachers and students of secondary schools. In the second phase, practical sheets were created that can be used for teaching not only at secondary vocational schools. On the way to school, students should be active, observing the surroundings, completing tasks, recording the results of their observations, discussing them with classmates and the teacher at school.

The approach is designed for students of secondary and secondary vocational schools and is based on the cross-curricular topic "Man and the environment". The main goal is to form a relationship with the environment based on newly acquired knowledge and skills, which is key to the environmentally sustainable behaviour of human society. The example of implementation of field learning is described in Table 1. 
The example of implementation of field learning with the support of worksheets

\begin{tabular}{|c|c|}
\hline Time/range & Activities \\
\hline $8: 00$ & Meeting in front of the school and departure to the locality \\
\hline $8: 16-9: 12$ & Travel by bus \\
\hline $9: 12-9: 30$ & Move to activity 1 \\
\hline $9: 30-9: 50$ & Activity 1 Memorial trees of the Czech Republic - St. Wenceslas Oak \\
\hline $9: 50-9: 55$ & Move to activity 2 \\
\hline $9: 55-10: 55$ & Activity 2 Landscape evaluation \\
\hline $10: 55-11: 05$ & Break - snack time \\
\hline $11: 05-11: 15$ & Move to activity 3 \\
\hline $11: 15-11: 45$ & Mctivity 3 Orchard - biotope or community space? \\
\hline $11: 45-12: 00$ & Move to activity 4 \\
\hline $12: 00-12: 20$ & Bctivity 4 NATURA House \\
\hline $12: 20-13: 40$ & Transfer to bus stop \\
\hline $13: 40-13: 50$ & Return by bus \\
\hline $13: 50-14: 48$ & Arrival to school, evaluation of activities, closure of the field learning \\
\hline $15: 00$ &
\end{tabular}

The set of worksheets designed by J. Hyklova (2019) contains the following topics:

- 1 Introduction - HUMANS AND THE ENVIRONMENT

- general terminology, basics of ecology and environment

- 2 On the way to school - THE WAY IS A GOAL

- orientation on the map, ecological transport, ecological footprint

- 3 On the way to school - CULTURAL LANDSCAPE

- definition and meaning of cultural landscape, location of the city

- 4 On the way to school - WATER

- water cycle, soil retention, importance of water elements in the landscape

- 5 On the way to school - BIRDS

- knowledge of urban bird species, synanthropy

- 6 On the way to school - TREES

- exploring deciduous and coniferous trees, the function of greenery in the town

To illustrate, we present a selection of worksheet \# 2 items focusing on "On the way to school - THE WAY IS A GOAL":

- On the attached map, mark the route along which you usually get to school.

- What is the distance between your home and school?

- How much time do you spend on the way every day? Do you use the time spent on the road for other activities?

- There are other variants of routes to get from your home to school. If so, mark them on the map and write, how often you use them.

- On the map, mark at least three places (points) that are important to you on the way to school. Justify why you marked them.

- Do you walk to school or do you use one of the means of transport?

- Assign, to the types of means of transport, their ecological footprint.

\section{The didactic approach by M. Orvanova (2019): Nature Educational Trail}

In addition, another author of the didactic approach believes in the importance of human ties with the environment. She accentuates the meaningfulness of walks with children to the nature from their early age, so that they know it well and like it, so that they build pro-ecological value orientations.

Thus, in accordance with the cross-curricular topic "Man and the environment", the author proposed an activity for secondary and secondary vocational school students, which would serve teachers in line with the concept of the topic to increase students' awareness of their surrounding natural environment. 
The activity itself is a design of a nature educational trail in the selected area of the Czech Republic. The area was analysed, including fauna, flora, environmental aspects of this locality, and difficulty of the route in terms of time allocation for teaching. The lesson arranged as a walk of the teacher and the students on the created educational trail is supported by the relevant worksheets for recording and describing the observed natural products, to record the results of their observations, to better remember the information and possibly to repeat it. The example of a worksheet is in Figure 1. Learning outcomes would take the form of their presentation and discussion within the Project Day.

\section{Worksheet No.6 A}

\section{Write which deciduous trees you can see on your way to school:}

\section{Determine which deciduous trees are shown in the figure below:}

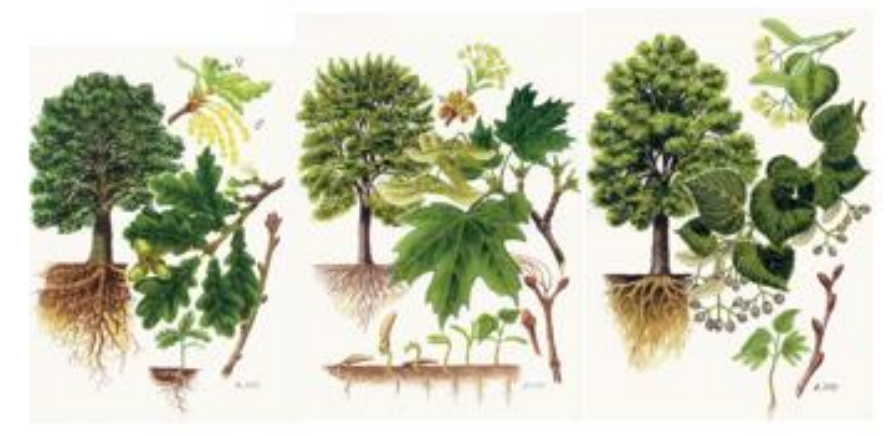

3. For the trees in the figure above, specify the following:

\begin{tabular}{|l|l|l|l|l|l|}
\hline & Kingdom & Class & Order & Family & Genus \\
\hline Tree 1 & & & & & \\
\hline Tree 2 & & & & & \\
\hline Tree 3 & & & & & \\
\hline
\end{tabular}

\section{Name at least three examples of the use of deciduous trees shown in the} picture above:

Figure 1. Demonstration of a worksheet focusing on increasing students' awareness of deciduous trees and their importance.

\section{Conclusions}

The authors are convinced that environmental awareness is the basis for a positive and committed relationship with the environment and nature. The topic "On the way to school", through the diversity of didactic approaches is an example of how to lead students to get to know their surroundings, how to critically evaluate it and find solutions to improve its quality and sustainability. From the didactic point of view, the form of field teaching and the method of project teaching and both independent and group work of students proved to be effective. Controlled observation and providing students with worksheets prepared by the teacher, which guide students' observations and independent activities and guide them to a more permanent memorization of observed natural products and phenomena, has also proved to be successful and significant. 


\section{Bibliography}

1. Cyrankowska M., Kostecka J., Mazur-Paczka A. (2019). The Role of Relationships in Teaching Content Important for Sustainable Development. In V. Dislere (Ed.), The Proceedings of the International Scientific Conference Rural Environment. Education. Personality (REEP), 12. Jelgava: Latvia University of Life Sciences and Technologies, 34-39. doi: 10.22616/REEP.2019.004

2. Dytrtova R. (2003). The Aims of Environmental Education in the Universities. In Proceedings of the International Symposium Environment and Universities in Europe, Konstanz: Universitat Konstanz, 209-212.

3. Dytrtova R. (2005). The Competencies of Teachers for Education to Sustainable Development. In Environmental Management for Education and Edification, 2(2), 4-9. Banská Bystrica, Slovakia: University of Matej Bel in Banská Bystrica.

4. Dytrtova R. (2006). Education towards Sustainable Development in the Systematic Conception of Didactic. In Environmental Management for Education and Edification, 3(1), 21-31, Banská Bystrica, Slovakia: University of Matej Bel in Banská Bystrica.

5. Dytrtova R. (2007). The Nature Protection in Education at Vocational Schools in the Czech Republic. In Natura, 45(2), 25-37.

6. Dytrtova R., Nemejc K. (2018). Evaluation of Awareness and Implementation of Environmental Education in Teachers of Secondary Vocational Schools. In V. Dislere (Ed.), The Proceedings of the International Scientific Conference Rural Environment. Education. Personality (REEP), 11. Jelgava: Latvia University of Life Sciences and Technologies, 66-73. doi: 10.22616/REEP.2018.007

7. Ehrlich P.R. (2011). A Personal View: Environmental Education - Its Content and Delivery. Journal of Environmental Studies and Sciences, 1, 6-13. doi: 10.1007/s13412-011-0006-3

8. Hyklova J. (2019). Cestou do školy: povědomí žáků středních odborných škol o okolním přirodním prostředí [On the Way to School: The Awareness of Students of Secondary Vocational Schools about their Surrounding Natural Environment]. (Graduation Thesis, Institute of Education and Communication, CZU Prague). (in Czech)

9. Mackay CM.L., Schmitt M.T. (2019). Do People Who Feel Connected to Nature Do More to Protect It? A meta-analysis. Journal of Environmental Psychology, 65, 101323. doi: 10.1016/j.jenvp.2019.101323

10. Nováková P., Němejc K., Dytrtová R. (2018). A Responsible Consumer of the 21st Century as a Part of Environmental Education at Secondary Vocational Schools: A Design of a Curricular Topic. In L. Gómez Chova, A. López Martínez, I. Candel Torres (Eds.), Proceedings of the International Conference of Education, Research and Innovation (ICERI2018), 11. Seville: IATED Academy, 7919-7924. doi: 10.21125/iceri.2018.0421

11. Orvanova M. (2019). Cestou do školy: povědomi žákư středních odborných škol o okolním prírodním prostředi [On the Way to School: The Awareness of Students of Secondary Vocational Schools about their Surrounding Natural Environment] (Bachelor's Thesis, Prague: Institute of Education and Communication, CZU Prague). (in Czech)

12. Scoullos M.J. (1998). Environment and Society: Education and Public Awareness for Sustainability. In Proceedings of the Thessaloniki International Conference, Thessaloniki: University of Athens, 17.

13. Sedivy V. (2020). Cestou do školy: povédomí žáků středních odborných škol o okolním př́rodním prostředí [On the Way to School: The Awareness of Students of Secondary Vocational Schools about their Surrounding Natural Environment]. (Bachelor's Thesis, Prague: Institute of Education and Communication, CZU Prague). (in Czech)

14. Sjoblom P., Wolff L.A. (2017). It wouldn't be the same without Nature" - The Value of Nature According to Finnish Upper Secondary School Students. The Journal of Environmental Education, 48(5), 322-333. doi: 10.1080/00958964.2017.1367637

15. Svacek S. (2019). Cestou do školy: povédomížáků středních odborných škol o okolním př́rodním prostředí [On the Way to School: The Awareness of Students of Secondary Vocational Schools about their Surrounding Natural Environment]. (Graduation Thesis, Prague: Institute of Education and Communication CZU Prague). (in Czech)

16. Vasilevska D., Geske A. (2020). Competency-Based Approach to Educational Content for Sustainable Development in Latvia. In V. Dislere (Ed.), The Proceedings of the International Scientific Conference Rural Environment. Education. Personality (REEP), 13. Jelgava: Latvia University of Life Sciences and Technologies, 340-347. doi: 10.22616/REEP.2020.041

17. Zhanguzhinova M.Y., Magauova A.S., Nauryzbaeva A.S. (2016). Competence Approach in Vocational Education of Kazakhstan in Conditions of Innovational and Industrial Development of the Society. In V. Dislere (Ed.), The Proceedings of the International Scientific Conference Rural Environment. Education. Personality (REEP), 9. Jelgava: LLU, 128-133. Retrieved from https://llufb.1lu.lv/conference/REEP/2016/Latvia-Univ-Agricult-REEP-2016proceed2255-808X-128-133.pdf 